\title{
INFLUENCE OF CHEMICAL COMPOSITION OF ACTIVATED CALCIUM BENTONITES AND SODIUM BENTONITES ON PALM OIL BLEACHING CAPACITY AND OIL QUALITY
}

\author{
DOLPHEN, $\mathbf{R}^{1}$; DHURAKIT, $\mathrm{P}^{2}$ and THIRAVETYAN, $\mathrm{P}^{2 *}$
}

\begin{abstract}
The efficiency of clays in bleaching degummed palm oil depends on their unique characteristics. This study sheds new light on a novel characteristic which impacts on the quality and bleaching capacity of activated clay. Although bentonites may originate from different areas, their structural modifications can make them ideally suited for bleaching. Calcium (Ca)-bentonites and sodium (Na)-bentonites, including activated forms of both clays, were investigated in depth. Interestingly, X-ray fluorescence (XRF) spectrometry indicated that the high bleaching capacity of $\mathrm{Na}$-bentonite was correlated with silica $\left(\mathrm{SiO}_{2}\right)$ and alumina $\left(\mathrm{Al}_{2} \mathrm{O}_{3}\right)$ contents in the range of $68.90 \%-85.20 \%$ and $8.96 \%-16.60 \%$ by weight (wt), respectively. The results showed that Na-bentonite treated with $1.5 \mathrm{M}$ sulphuric acid $\left(\mathrm{H}_{2} \mathrm{SO}_{4}\right)$ at a clay:acid ratio of 10:50 $\left(w v^{-1}\right)$ and refluxing time of $8 \mathrm{hr}$ had a higher bleaching capacity (78.04\%) than commercial clay (67.09\%). These characteristics can provide a suitable reaction space at the interlayer for adsorption of pigments and impurities. Moreover, the specific surface area and total pore volume of this activated clay also increased. After bleaching by treated $\mathrm{Na}$-bentonite with $1.5 \mathrm{M} \mathrm{H}_{2} \mathrm{SO}_{4}$, degummed palm oil appeared to be of good quality, leading to less deterioration and rancidity due to decreased free fatty acid (FFA), unsaturated fatty acid, iron $(\mathrm{Fe})$ and phosphorus $(\mathrm{P})$ contents.
\end{abstract}

\section{Keywords: bleaching, calcium bentonite, colour, palm oil, sodium bentonite.}

Received: 27 October 2020; Accepted: 25 August 2021; Published online: 29 October 2021.

\section{INTRODUCTION}

Crude palm oil (CPO) is found to contain pigments, such as carotenoids, especially $\beta$-carotene, and their derivatives xanthophylls, chlorophyll, pheophytin, tocopherols and gossypol, as well as oxidised fatty acids, trace soaps and trace metals [copper ions

\footnotetext{
Pilot Plant Development and Training Institute, King Mongkut's University of Technology Thonburi, Bangkok 10150, Thailand.

2 Division of Biotechnology, School of Bioresources and Technology, King Mongkut's University of Technology Thonburi, Bangkok 10150, Thailand.

* Corresponding author e-mail: paitip.thi@kmutt.ac.th
}

$\left(\mathrm{Cu}^{2+}\right)$, ferric ions $\left.\left(\mathrm{Fe}^{3+}\right)\right]$ (Rossi et al., 2011), which negatively influence the taste, smell and colour of the oil. Thus, removal of these substances causes a light yellowish colour and improves the stability and sensory quality of the oil for greater acceptance by consumers.

Bleaching is one of the most important steps in vegetable oil refining; in this step, pigments and undesirable impurities are removed by a process involving van der Waals forces and covalent bonds (Nwabanne and Ekwu, 2013). The efficiency of palm oil bleaching has been reported in many types of adsorbents such as palm oil boiler ashes, activated coconut pod ash, perlite, smectite, activated kaolinite, pyrolysis waste material peanut hulls, press mud, rice husks and synthetic 
silica) (Ismail et al., 2016; Lau et al., 2019; Meesuk and Seammai, 2010; Rossi et al., 2003; Warasith and Goodman, 2020; Tebandeke et al., 2014). However, adsorption materials used nowadays throughout the world by vegetable oil refiners are mainly activated montmorillonite clays due to its structural unit consisting of an octahedral alumina sheet sandwiched between two sheets of tetrahedral silica. Bentonite consists mostly of montmorillonite and has been widely employed in refining edible oil because its swelling, adsorption capacity and surface acidity properties make it suitable for wide variety of applications (Ayari et al., 2005). Numerous literature reports affirm that the activation of bentonites with acids such as sulphuric, hydrochloric and oxalic acids, as well as anionic and cationic surfactants, could increase their adsorbent properties (Gunawan et al., 2010; Joy et al., 2007; Salawudeen et al., 2007; Warasith and Goodman, 2020). Activation is expected to improve certain features of clay, such as its specific surface area, porosity, functional groups and framework collapse and, thereby, its bleaching capacity (Aung et al., 2014; Joy et al., 2007; Kashani Motlagh et al., 2011; Nde et al., 2019; Nwabanne and Ekwu; 2013; Silva et al., 2013; Usman et al., 2013). As mentioned above, various research efforts on the best conditions for modified clays and then new bleaching clays were investigated in terms of their characteristics and mechanisms for bleaching oil. However, it is difficult to control the quality of clays after modification because they originate from various locales, which affects their properties (Afolabi et al., 2017). Therefore, this study sheds new light on a novel characteristic of bentonites which impacts the quality and bleaching capacity of activated clay. Although bentonite clays are sourced from different areas, the preparation of clays should result in suitable amounts of the major constituents, especially silica $\left(\mathrm{SiO}_{2}\right)$ and alumina $\left(\mathrm{Al}_{2} \mathrm{O}_{3}\right)$. There are no reports about the influence of the chemical composition of bentonites after activation on bleaching capacity. For instance, in the case of kaolin, which has a different clay structure from that of bentonite, suitable $\mathrm{SiO}_{2}$ and $\mathrm{Al}_{2} \mathrm{O}_{3}$ contents of activated kaolin for rice bran oil bleaching were approximately $62.40 \%-65.10 \%$ and $31.20 \%-4.20 \%$, respectively (Aung et al., 2015).

Therefore, the aim of this research was to determine a suitable chemical composition in the structure of activated Ca-bentonites and Na-bentonites to predict clay quality in the bleaching process. The correlation between unique characteristics such as chemical composition $\left(\mathrm{SiO}_{2^{\prime}}\right.$ $\mathrm{Al}_{2} \mathrm{O}_{3}$, iron (III) oxide $\left(\mathrm{Fe}_{2} \mathrm{O}_{3}\right)$ and magnesium oxide $(\mathrm{MgO})$ contents) in clays and bleaching capacities were evaluated. Meanwhile, the crystal structure, surface area and pore volume were characterised to support the properties of the clays. In addition, aspects of oil quality after bleaching, such as free fatty acids (FFA), moisture content, peroxide value, iodine value and iron $(\mathrm{Fe})$ and phosphorus $(\mathrm{P})$ contents, were investigated.

\section{MATERIALS AND METHODS}

\section{Materials}

Samples of Ca-bentonite and Na-bentonite were obtained from Thep Agricultural Industry Co., Ltd., Thailand. The clay samples were dried at $70^{\circ} \mathrm{C}$ for $24 \mathrm{hr}$ and sieved through 200 mesh to obtain particles $(75 \mu \mathrm{m})$. Commercial bleaching clay (montmorillonite) obtained from Taiko Clay Marketing, Malaysia was used as the reference clay for the bleaching tests. Degummed palm oil was obtained from Oleen Co., Ltd., Thailand. This oil had an orange-red appearance and contained 49.9 red and 5.9 yellow Lovibond units (Lovibond Tintometer Model F, Tintometer Ltd., United Kingdom).

\section{Refluxing Process}

Ten-gram bentonite samples were introduced into a round-bottom flask, $500 \mathrm{ml}$ of sulphuric acid $\left(\mathrm{H}_{2} \mathrm{SO}_{4}\right)$ in concentrations of $0.2-5.0 \mathrm{M}$ was added to give a 1:50 ( $\left.\mathrm{w} \mathrm{v}^{-1}\right)$ clay:acid ratio, and the mixture was then heated at $90^{\circ} \mathrm{C}$ for $4 \mathrm{hr}$ under agitation. In the case of pre-heated materials, bentonites were prepared by heating in a muffle furnace at $300^{\circ} \mathrm{C}-700^{\circ} \mathrm{C}$ for $1 \mathrm{hr}$. Then, $10 \mathrm{~g}$ of each heated sample was refluxed with $500 \mathrm{ml}$ of $2.0 \mathrm{M} \mathrm{H}_{2} \mathrm{SO}_{4}$ in a round-bottom flask under agitation at $90^{\circ} \mathrm{C}$ for $4 \mathrm{hr}$. Sodium bentonite samples were treated with various $\mathrm{H}_{2} \mathrm{SO}_{4}$ concentrations (0.6-3.0 M) at clay:acid ratios of 1:50, 5:50 and 10:50 $\left(\mathrm{w} \mathrm{v}^{-1}\right)$, followed by refluxing at $90^{\circ} \mathrm{C}$ under agitation. The refluxing time was varied between $4,6,8$ and $10 \mathrm{hr}$.

Next, the samples were washed several times with distilled water until the solution reached $\mathrm{pH} 3$, corresponding to the optimum $\mathrm{pH}$ for bleaching of vegetable oil (Girgis, 2005). Subsequently, the samples were oven-dried at $80^{\circ} \mathrm{C}$ for $24 \mathrm{hr}$ to reduce the moisture content, crushed into a powder form and sieved through 400 mesh. All samples were stored at room temperature for further experiments.

\section{Bleaching Experiments}

One-hundred-milligram clay samples were added into $10 \mathrm{ml}$ of $\mathrm{CPO}$, and then the mixtures were heated at $90^{\circ} \mathrm{C}$ in an oil bath for 30 min under constant agitation. After that, the oil samples were centrifuged at $4500 \mathrm{rpm}$ for $15 \mathrm{~min}$ and then filtered through Whatman No. 5 filter paper. The bleaching process was performed in triplicate. Finally, the 
colours of the palm oil samples were measured in a spectrophotometer at $450 \mathrm{~nm}$ (Thermo Scientific ${ }^{\mathrm{TM}}$, type Evolution 201, Waltham, MA, USA). The bleaching capacities were calculated according to Equation (1):

$$
\text { Bleaching capacity }(\%)=\left[\left(A_{0}-A\right) / A_{0}\right] \times 100
$$

where $A_{0}$ and $A$ are the absorbances of the unbleached and bleached oil at $450 \mathrm{~nm}$, respectively.

\section{Characterisation of Clays by X-ray Diffraction (XRD), X-ray Fluorescence (XRF) and Measurement of Pore Structure}

The XRD patterns of samples were recorded using a D8 Advance powder diffractometer (Bruker AXS, Germany) with $\mathrm{Cu}-\mathrm{K} \alpha$ radiation at $\lambda=1.54056$ $\AA$, operated at $40 \mathrm{kV}$ and $40 \mathrm{~mA}$ in the range of $10^{\circ}$ $100^{\circ}$. A wavelength-dispersive $X$-ray fluorescence (WD-XRF) spectrometer (model S4 Pioneer, Bruker AXS, Germany) was used to determine the elements present in clay samples. The XRF spectrometer was equipped with a 4 -W Rh anode X-ray tube, $60-\mathrm{kV}$ generators, and eight diffracting crystals of various diffraction spacings. The porous properties of clay samples were measured by the adsorptiondesorption isotherms of nitrogen gas with a surface area analyser (Autosorb-1, Quantachrome Instruments, USA). The Brunauer-Emmett-Teller (BET) equation was applied to estimate the specific surface area, total pore volume, micropore volume and average pore size of samples.

\section{Physicochemical Characterisation of Palm Oil}

Initial crude oils and bleached oils were characterised by assessment of moisture content (method Ca 2c-25), FFA (method Ca 5a-40), iodine value (method $\mathrm{Cd} 1 \mathrm{c}-85$ ), peroxide value (method 965.32) and fatty acid composition (method Ce 1e91) (Cunniff, 1997; Firestone, 1997). The colour of oil samples was estimated using a 5 1/4" path length and a Lovibond Tintometer Model F, according to method Cc 13b-45 (Firestone, 1997). In addition, the oil samples were ashed according to the AOAC 999.11 method for Fe and P analysis (Jorhem, 2000). Fe content was determined using inductively coupled plasma optical emission spectrometry (ICP OES; Horiba, JY2000, Japan), while the P content was determined by the colorimetric method.

\section{Statistical Analysis}

The data were statistically analysed by one-way analysis of variance (ANOVA) using the Statistical Package for Social Sciences (SPSS). Significantly, different means were assessed by Duncan's multiple range test $(\mathrm{p}<0.05)$.

\section{RESULTS AND DISCUSSION}

Bentonite is aluminium phyllosilicate clay that consists mostly of montmorillonite but also contains impurities and is classified into $\mathrm{Na}$ or Ca types, depending on the dominant exchangeable cations (Hassan and Abdel-Khalek, 1998). Based on this classification procedure, Ca-bentonite and Nabentonite were categorised as calcium (Ca-bentonite) and sodium Na-bentonite) types, respectively. In this study, however, the XRD pattern indicated that montmorillonite was a major component of bentonites (Figure 1).

Commercial clay (montmorillonite) has a bleaching potential for degummed palm oil of approximately $67.09 \%$, while original of Cabentonite and Na-bentonite can bleach this oil approximately $9.02 \%$ and $0.89 \%$, respectively. This may be due to the unique characteristics of these clays. Commercial clay, Ca-bentonite, and Nabentonite are mainly composed of $\mathrm{SiO}_{2}, \mathrm{Al}_{2} \mathrm{O}_{3}$ and $\mathrm{Fe}_{2} \mathrm{O}_{3}$. The $\mathrm{SiO}_{2}$ and $\mathrm{Al}_{2} \mathrm{O}_{3}$ contents in commercial clay used for bleaching degummed palm oil are $80.70 \%$ and $10.20 \%$, respectively. The XRF results of commercial clay showed a higher $\mathrm{SiO}_{2}$ content $(80.70 \%)$ than was found in Ca-bentonite $(66.40 \%)$ and Na-bentonite $(48.40 \%)$, while $\mathrm{Al}_{2} \mathrm{O}_{3}(10.20 \%)$ showed a lower content than was found in Cabentonite and Na-bentonite $(20.30 \%$ and $19.40 \%$, respectively) (Figures 2 and 3 ).

$\checkmark$ The element composition and content of clay structure can change the clay's unique characteristics. Interestingly, this study proposes that the bleaching capacity of degummed palm oil is related to suitable $\mathrm{SiO}_{2}$ and $\mathrm{Al}_{2} \mathrm{O}_{3}$ contents. After acid activation, the crystallinity of Ca-bentonite and Na-bentonite was not changed (Figure 1) but the structure of Ca-bentonite and Na-bentonite was modified, as indicated by the change in the chemical composition, especially the $\mathrm{SiO}_{2}$ and $\mathrm{Al}_{2} \mathrm{O}_{3}$ contents (Figures 2 and 3). This might be because the exchangeable cations and impurity elements in the interlayer cations were replaced by hydrogen ions $\left(\mathrm{H}^{+}\right)$ions, after which dissolution of elements in the octahedral sheet occurred. With increasing acid concentration, the $\mathrm{SiO}_{2}$ content increased while the $\mathrm{Al}_{2} \mathrm{O}_{3}, \mathrm{Fe}_{2} \mathrm{O}_{3}, \mathrm{MgO}$, calcium oxide $(\mathrm{CaO})$, sodium oxide $\left(\mathrm{Na}_{2} \mathrm{O}\right)$, and potassium oxide $\left(\mathrm{K}_{2} \mathrm{O}\right)$ contents decreased, possibly because leaching was likely to occur in octahedral and exchangeable cations. On treatment of Na-bentonite with various $\mathrm{H}_{2} \mathrm{SO}_{4}$ concentrations, $\mathrm{Na}$ minerals were increasingly eluted from the interlayer of the clay, demonstrating that calcium ions $\left(\mathrm{Ca}^{2+}\right)$ and magnesium ions $\left(\mathrm{Mg}^{2+}\right)$ were the main exchangeable cations rather than $\mathrm{Na}$. Meanwhile, $\mathrm{Ca}^{2+}$, potassium ions $\left(\mathrm{K}^{+}\right), \mathrm{Mg}^{2+}$ and sodium ions $\left(\mathrm{Na}^{+}\right)$still appeared in $\mathrm{H}_{2} \mathrm{SO}_{4}^{-}$ treated bentonite samples as exchangeable cations in the interlayer. The best activation condition was 
Na-bentonite refluxed with 1.5-3.0 $\mathrm{M} \mathrm{H}_{2} \mathrm{SO}_{4}$ solution, which correlated positively with $\mathrm{SiO}_{2}$ and $\mathrm{Al}_{2} \mathrm{O}_{3}$ contents in the range of $74.80 \%-85.20 \%$ and $8.96 \%$ $13.30 \%$ by weight $(\mathrm{wt})$, respectively, which was close to the composition of commercial clay.

It has been well documented that the orangered pigmentation of degummed palm oil is mainly due to the presence of carotenoid compounds. Decolourisation of palm oil from orange-red to pale yellow improves the oil's appearance. In this study, XRF characterisation of Ca-bentonite, Nabentonite and both activated clays revealed an association between the bleaching capacity and the $\mathrm{SiO}_{2}$ and $\mathrm{Al}_{2} \mathrm{O}_{3}$ contents. By increasing the $\mathrm{H}_{2} \mathrm{SO}_{4}$ concentration from $0.2-5.0 \mathrm{M}$ in the activation of Ca-bentonites, the $\mathrm{SiO}_{2}$ content was increased from $71.00 \%$ to $80.00 \%$. This clay could remove less than $30.00 \%$ of the colour, and the palm oil remained orange-red (Figure 2). After activation of bentonite with $5.0 \mathrm{M} \mathrm{H}_{2} \mathrm{SO}_{4}$, the bleaching capacity tended to increase up to $38.95 \%$, likely due to the high acid concentration used, which induced leaching of aluminium $(\mathrm{Al})$ and the elements from the interlayer cations, and the $\mathrm{SiO}_{2}$ content increased by up to $87.30 \%$. In addition, when the Ca-bentonites were preheated to $300^{\circ} \mathrm{C}$ and $500^{\circ} \mathrm{C}$ for $1 \mathrm{hr}$ in a muffle furnace prior to refluxing with $2.0 \mathrm{M} \mathrm{H}_{2} \mathrm{SO}_{4}$ (F300 CBR 2.0 and F500 CBR 2.0), there was also an increase in $\mathrm{SiO}_{2}$ content from $88.70 \%$ to $89.70 \%$, and the $\mathrm{Al}_{2} \mathrm{O}_{3}$ content tended to decrease slightly from $7.10 \%$ to $6.55 \%$, leading to a slightly increased bleaching capacity of $40.70 \%-53.33 \%$ (Figure 2). Clays preheated at a high temperature before activation display a higher specific surface area and total pore volume than non-preheated samples, as the clay is fully converted to an amorphous phase, which can easily leach aluminium ions $\left(\mathrm{Al}^{3+}\right)$ and exchangeable cations (Fernandez et al., 2011; Foo et al., 2011). Preheating of the Ca-bentonites at $700^{\circ} \mathrm{C}$ for $1 \mathrm{hr}$ in a muffle furnace prior to refluxing with $2.0 \mathrm{M} \mathrm{H}_{2} \mathrm{SO}_{4}$ (F700 CBR 2.0), which showed a high $\mathrm{SiO}_{2}$ content $(92.30 \%$ by wt) and a low $\mathrm{Al}_{2} \mathrm{O}_{3}$ content (left only $4.28 \%$ by wt), was not favourable for the sorption of organic pigment and was ineffective for the decolourisation of palm oil ( $18.47 \%$ bleaching only) (Figure 2). This was possibly due to extensive leaching of the $\mathrm{Al}_{2} \mathrm{O}_{3}$ content, resulting in disruption or destruction of the clay sheets, which negatively affected the bleaching capacity.



Figure 1. XRD patterns of (a) commercial clay, Ca-bentonite, and activated Ca-bentonites, and (b) Na-bentonite and activated Na-bentonites. 
a)

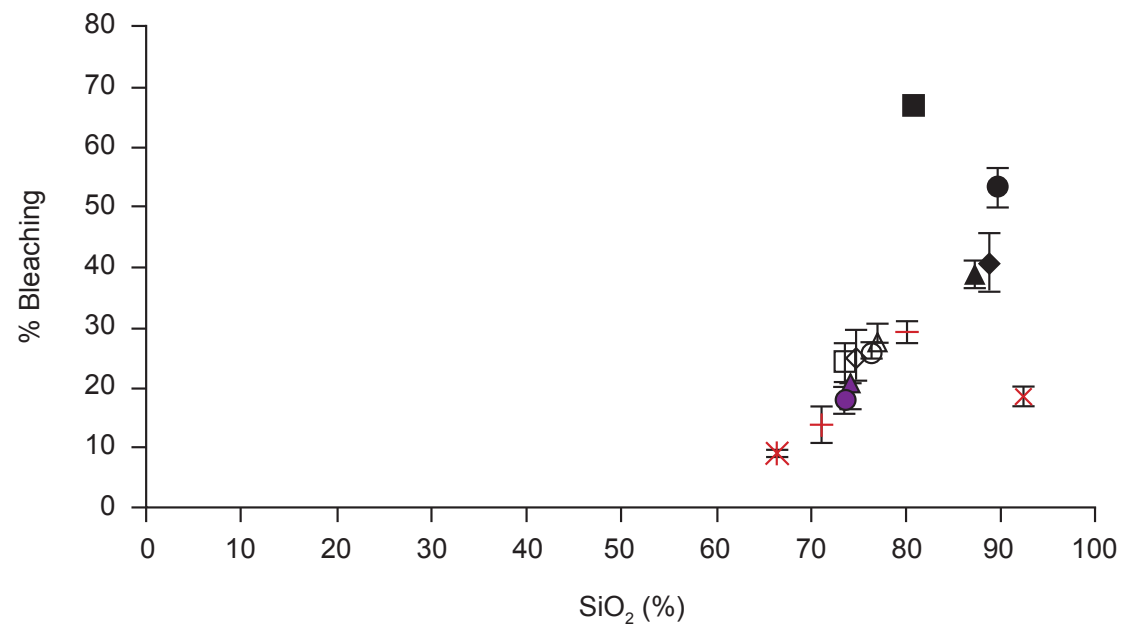

b)

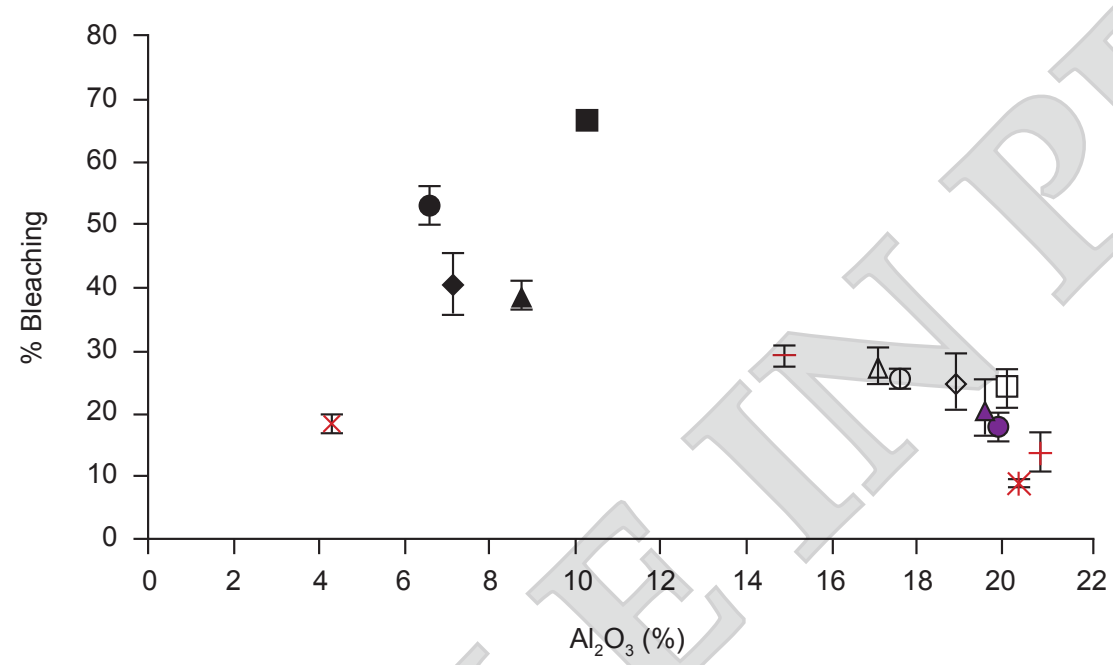

Commercial clay

* Ca-bentonite (original)

+ CBR 0.2

CBR 0.4

$\triangle$ CBR 0.8

$\square$ CBR 1.0

$\diamond$ CBR 1.2

O CBR 1.5

$\triangle$ CBR 1.8

- CBR 2.0

$\triangle$ CBR 5.0

F300 CBR 2.0

- F500 CBR 2.0

$\times$ F700 CBR 2.0

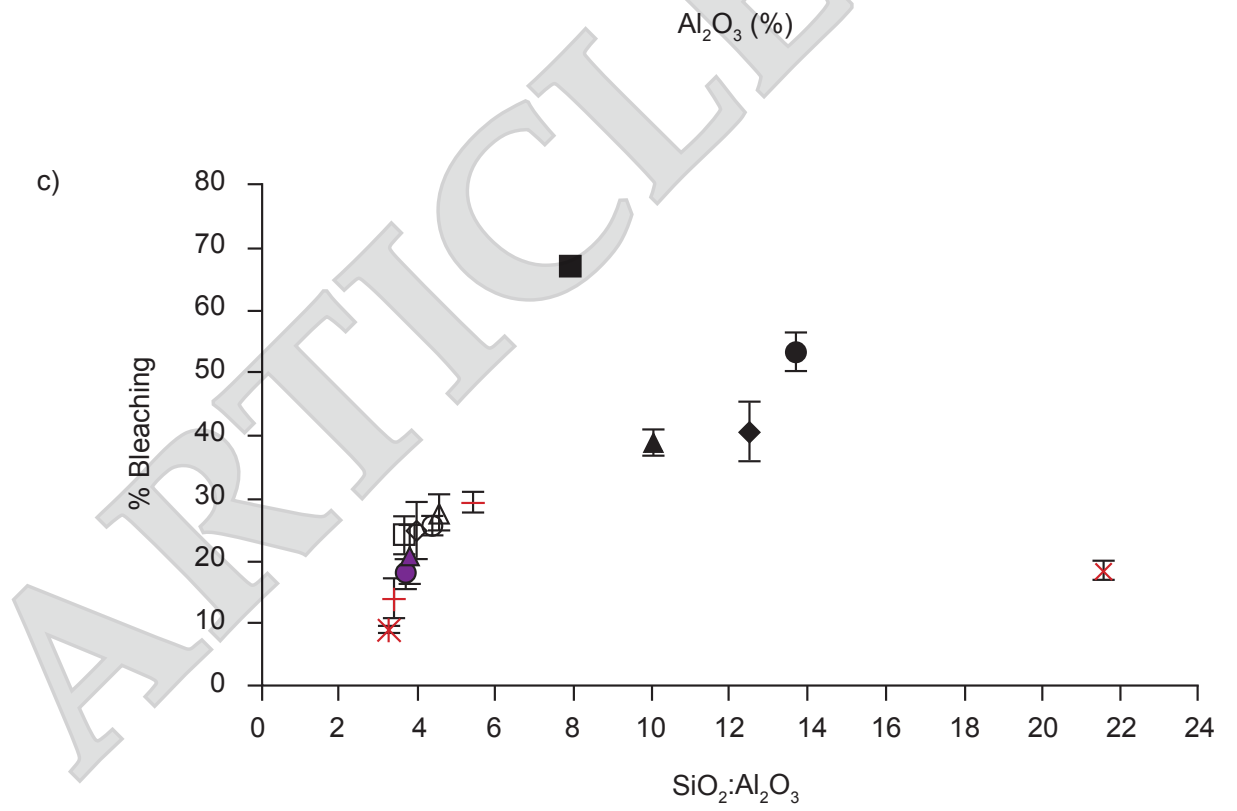

Note: CBR 0.2, CBR 0.4, CBR 0.8, CBR 1.0, CBR 1.2, CBR 1.5, CBR 1.8, CBR 2.0, CBR 5.0 = refluxing bentonite with $\mathrm{H}_{2} \mathrm{SO}_{4}$ solution with $0.2-$ $5.0 \mathrm{M}$ at $90^{\circ} \mathrm{C}$ for $4 \mathrm{hr}$ and the ratio of clays to acid was 1:50 $\left(\mathrm{w} \mathrm{v}^{-1}\right)$; F300 CBR 2.0, F500 CBR 2.0 and F700 CBR 2.0 = Ca-bentonites preheated at $300^{\circ} \mathrm{C}, 500^{\circ} \mathrm{C}$ and $700^{\circ} \mathrm{C}$ for $1 \mathrm{hr}$ in a muffle furnace prior to refluxing with $2.0 \mathrm{M} \mathrm{H}_{2} \mathrm{SO}_{4}$ at $90^{\circ} \mathrm{C}$ for $4 \mathrm{hr}$ and the ratio of clays to acid was 1:50 $\left(\mathrm{w} \mathrm{v}^{-1}\right)$.

Figure 2. The relationship between \% bleaching of palm oil and $\mathrm{SiO}_{2}$ contents (a), $\mathrm{Al}_{2} \mathrm{O}_{3}$ contents (b), and the ratio of $\mathrm{SiO}_{2}$ to $\mathrm{Al}_{2} \mathrm{O}_{3}$ contents (c) of commercial clay, Ca-bentonite, and activated Ca-bentonite under various conditions. 
a)

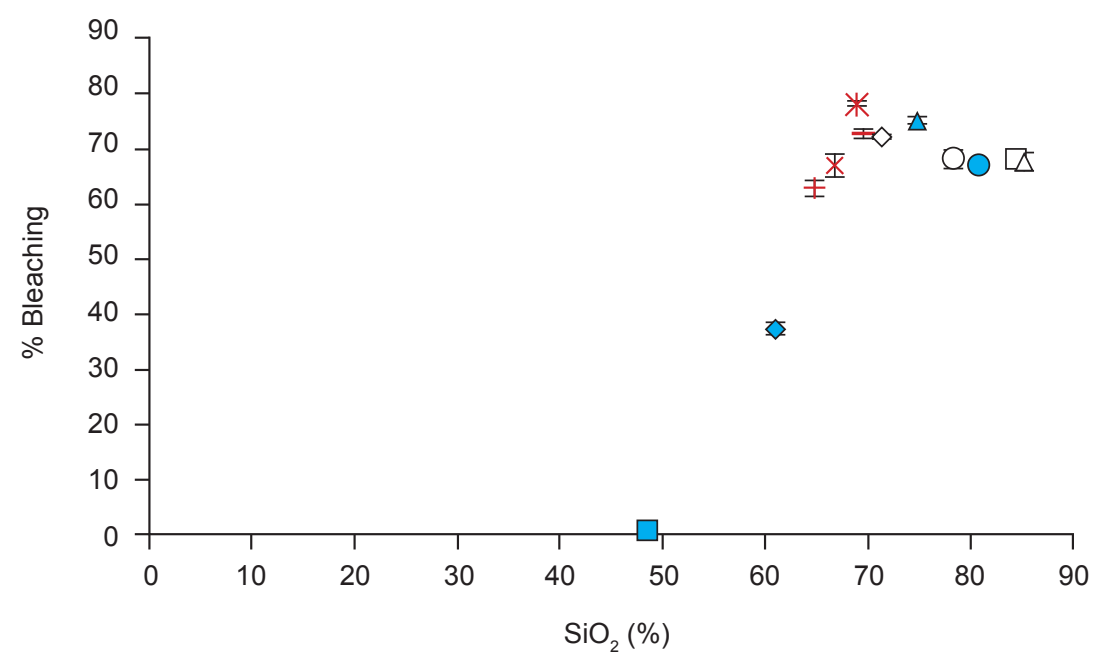

b)

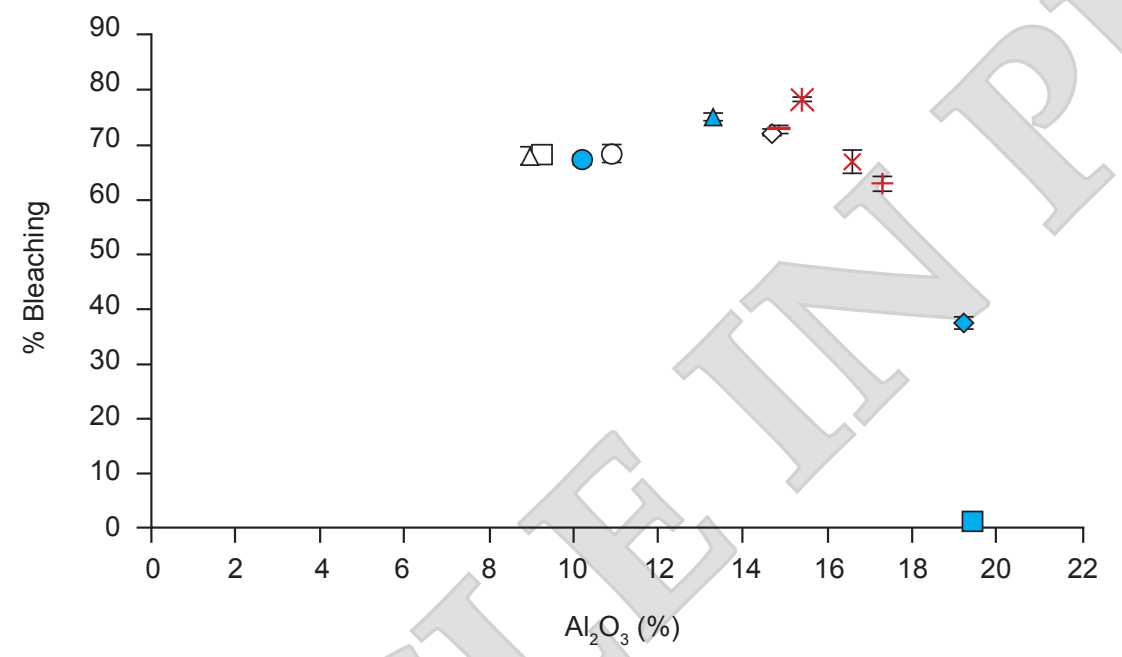

c)

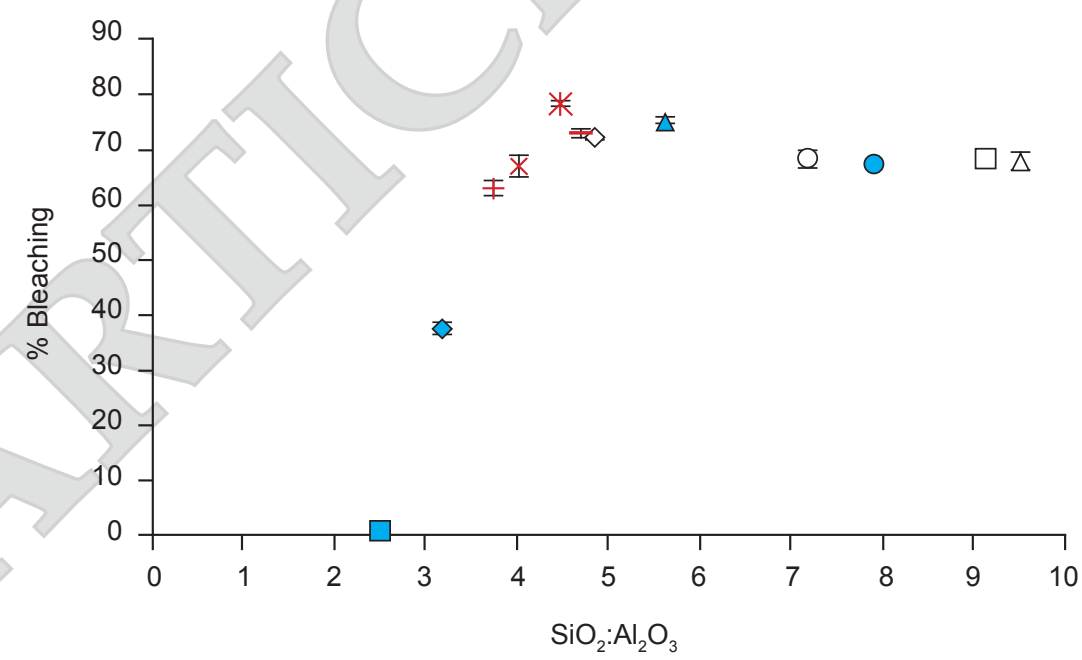

Note: SBR 0.6 (1:50, 4 hr), SBR 1.5 (1:50, 4 hr), SBR 2.0 (1:50, 4 hr), SBR 2.5 (1:50, 4 hr), SBR $3.0(1: 50,4$ hr) = refluxing Na-bentonite with $\mathrm{H}_{2} \mathrm{SO}_{4}$ solution with $0.6-3.0 \mathrm{M}$ at $90^{\circ} \mathrm{C}$ for $4 \mathrm{hr}$ and the ratio of clays to acid was 1:50 ( $\left.\mathrm{w} \mathrm{v}^{-1}\right)$. SBR 1.5 (5:50, $\left.4 \mathrm{hr}\right), \mathrm{SBR} 1.5(10: 50,4 \mathrm{hr})$, SBR $1.5(10: 50,6 \mathrm{hr})$, SBR $1.5(10: 50,8 \mathrm{hr})$, and SBR $1.5(10: 50,10 \mathrm{hr})=$ refluxing Na-bentonite with $1.5 \mathrm{M} \mathrm{H}_{2} \mathrm{SO}_{4}$ concentration at $90^{\circ} \mathrm{C}$ for 4-10 hr and the ratio of clays to acid was 5:50 $\left(\mathrm{w} \mathrm{v}^{-1}\right)$ and 10:50 $\left(\mathrm{w} \mathrm{v}^{-1}\right)$, respectively.

Figure 3. The relationship between \% bleaching of palm oil and $\mathrm{SiO}_{2}$ contents (a), $\mathrm{Al}_{2} \mathrm{O}_{3}$ contents (b), and the ratio of $\mathrm{SiO}_{2}$ to $\mathrm{Al}_{2} \mathrm{O}_{3}$ contents (c) of commercial clay, Na-bentonite, and activated Na-bentonite under various conditions. 
Although other studies mentioned that activated bentonite clay had a high efficiency for pigment removal (Christidis and Kosiari, 2003; Nde et al., 2019; Silva et al., 2013), our results illustrated that acid-activated bentonites had a low bleaching efficiency. This might be because the properties of bentonite and activated bentonites were not suitable for decolourisation of palm oil. Interestingly, the highest bleaching capability was observed for $\mathrm{Na}-$ bentonite activated by $1.5 \mathrm{M} \mathrm{H}_{2} \mathrm{SO}_{4}$ [clay:acid ratio of $1: 50\left(\mathrm{w} \mathrm{v}^{-1}\right), 4 \mathrm{hr}$ ] containing $74.80 \% \mathrm{SiO}_{2}$ and $13.30 \% \mathrm{Al}_{2} \mathrm{O}_{3}$; it could remove more colour from palm oil $(75.09 \%)$ than commercial clay $(67.09 \%)$. Meanwhile, the bleaching capacities of Na-bentonite activated with a high concentration of $\mathrm{H}_{2} \mathrm{SO}_{4}$ were not significantly different from those of commercial clay $(68.21 \%, 68.32 \%$ and $67.86 \%$ for $2.0,2.5$ and $3.0 \mathrm{M} \mathrm{H}_{2} \mathrm{SO}_{4}$ Na-bentonite, respectively), and its $\mathrm{SiO}_{2}$ and $\mathrm{Al}_{2} \mathrm{O}_{3}$ contents were $78.30 \%-85.20 \%$ and $10.90 \%-8.96 \%$, respectively (Figure 3). Moreover, no relationship was observed between these clays and the amount of $\mathrm{Ca}$, titanium ( $\mathrm{Ti}$ ), and $\mathrm{K}^{+}$, while the $\mathrm{Fe}_{2} \mathrm{O}_{3}$ and $\mathrm{MgO}$ contents of activated Na-bentonites (1.5-3.0 $\mathrm{M} \mathrm{H}_{2} \mathrm{SO}_{4}$ ) also influenced the bleaching efficiency of palm oil (Figures $4 a$ and $4 b$ ). On the other hand, a decline in the bleaching ability of clays was observed when a lower $\mathrm{H}_{2} \mathrm{SO}_{4}$ concentration $(0.6 \mathrm{M})$ was used, which led to a different range of $\mathrm{SiO}_{2}$ and $\mathrm{Al}_{2} \mathrm{O}_{3}$ contents $(60.90 \%$ and $19.20 \%$, respectively) (Figures $3 a$ and $3 b$ ). These results suggested that the highest bleaching of degummed palm oil was correlated with $\mathrm{SiO}_{2}$ and $\mathrm{Al}_{2} \mathrm{O}_{3}$ contents in the range of $74.80 \%-85.20 \%$ and $8.96 \%-13.30 \%$ by $\mathrm{wt}$, respectively, with a $\mathrm{SiO}_{2}: \mathrm{Al}_{2} \mathrm{O}_{3}$ ratio of 5.62-9.51 (Figure 3). This result suggested that the amount of $\mathrm{H}^{+}$ions increased when the acid concentration was increased, which caused remobilisation of the tetrahedral layers of silicon ions and delamination or depletion of cations such as $\mathrm{Al}^{3+}, \mathrm{Mg}^{2+}$ and $\mathrm{Fe}^{3+}$ from octahedral layers (Rossi et al., 2011; Temuujin et al., 2006) and then caused structural changes and partially decomposed the clay.

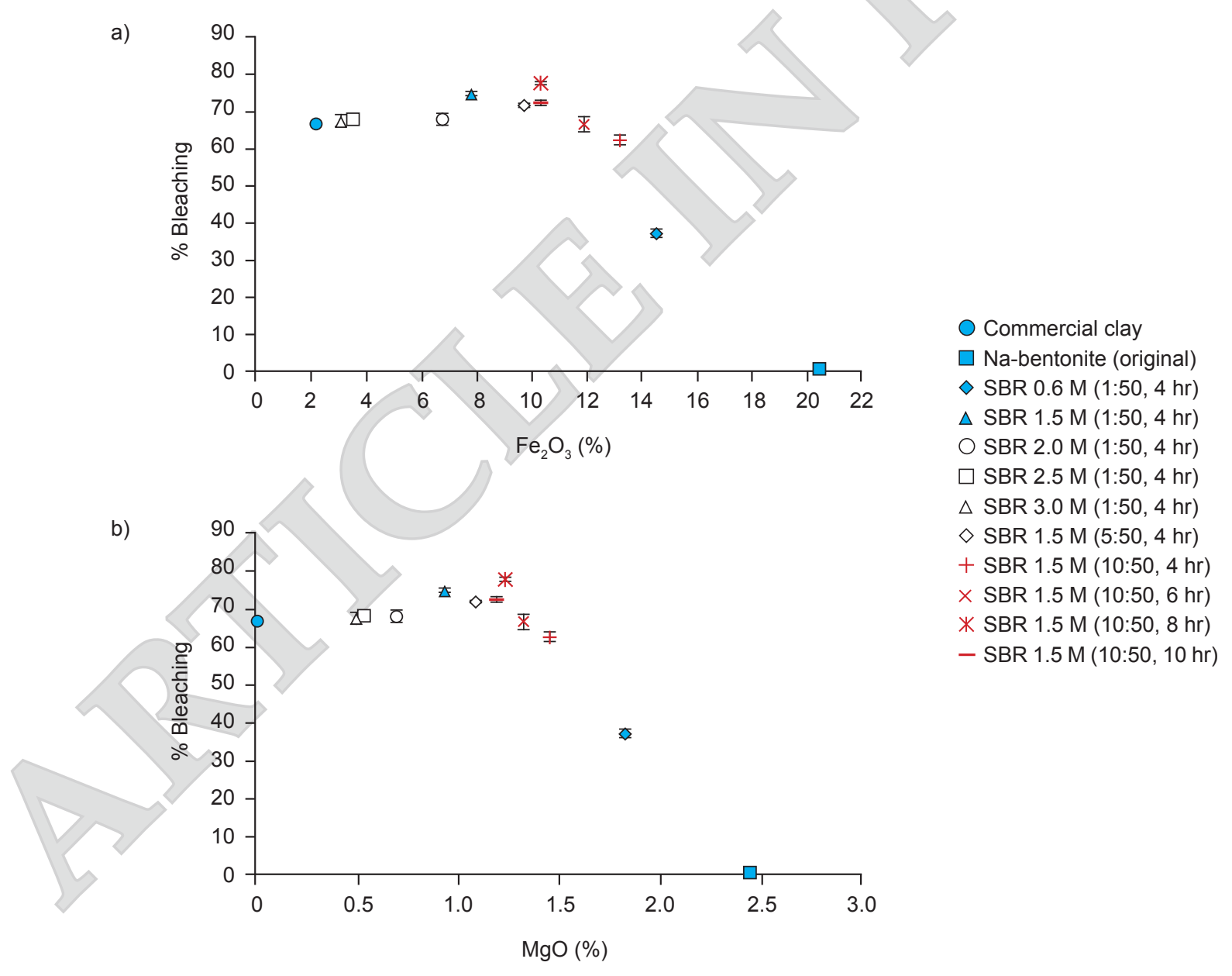

Note: SBR 0.6 (1:50, 4 hr), SBR 1.5 (1:50, 4 hr), SBR 2.0 (1:50, 4 hr), SBR 2.5 (1:50, 4 hr), SBR $3.0(1: 50,4 \mathrm{hr})=$ refluxing Na-bentonite with $\mathrm{H}_{2} \mathrm{SO}_{4}$ solution with $0.6-3.0 \mathrm{M}$ at $90^{\circ} \mathrm{C}$ for $4 \mathrm{hr}$ and the ratio of clays to acid was 1:50 ( $\left.\mathrm{w} \mathrm{v}^{-1}\right)$. SBR 1.5 (5:50, $\left.4 \mathrm{hr}\right), \mathrm{SBR} 1.5(10: 50,4 \mathrm{hr})$, SBR 1.5 (10:50, $6 \mathrm{hr})$, SBR $1.5(10: 50,8 \mathrm{hr})$, and SBR $1.5(10: 50,10 \mathrm{hr})=$ refluxing Na-bentonite with $1.5 \mathrm{M} \mathrm{H}_{2} \mathrm{SO}_{4}$ concentration at $90^{\circ} \mathrm{C}$ for 4-10 hr and the ratio of clays to acid was 5:50 $\left(\mathrm{w} \mathrm{v}^{-1}\right)$ and 10:50 $\left(\mathrm{w} \mathrm{v}^{-1}\right)$, respectively. 
In addition, Lovibond analysis showed that the colour of the degummed palm oil was 49.9 red and 5.9 yellow Lovibond units, whereas that bleached with $1.5 \mathrm{M} \mathrm{H}_{2} \mathrm{SO}_{4} \mathrm{Na}$-bentonite had a colour of 16.9 red and 79.9 yellow units and was a lighter yellow than commercial clay (23.4 red and 41.8 yellow units). Therefore, although Na-bentonite clays come from different areas, the preparation of clays should give suitable $\mathrm{SiO}_{2}$ and $\mathrm{Al}_{2} \mathrm{O}_{3}$ contents.

FFA is one of the factors that can affect oil quality. Oil bleached by commercial clay and $1.5 \mathrm{M}$ $\mathrm{H}_{2} \mathrm{SO}_{4}$ Na-bentonite showed FFA (as palmitic acid) concentrations of $8.99 \%$ and $8.94 \%$, respectively, whereas the degummed palm oil had a fatty acid content of $13.65 \%$ (Table 1). Presented results here on the adsorption of FFA were in agreement with those reported in a previous work (Joy et al., 2007), although normally FFA adsorption was found during discolouration. The adsorption of FFA of oil is described by the diffusion of FFA from oil to the active site of the clay followed by the interaction between adsorbate and the active site (Baptiste et al., 2020). The analysis of adsorptive properties reveals that activated Na-bentonites had a large specific surface, total pore volume and microporous, which gives them great adsorption properties (Table 2). Although activation of Na-bentonites could decrease their FFA content, the FFA content of activated Na-bentonites remained higher than standard specifications. For trading purposes, the maximum FFA content set by the Palm Oil Refiners Association of Malaysia in $\mathrm{CPO}$ is $5 \%$, indicating that the use of low-quality $\mathrm{CPO}$ with a relatively high FFA content as the input of the bleaching process might result in a low smoke point and, consequently, high impairment of oil quality (Khor et al., 2019). The lengthy storage period of the CPO used in the study might have affected FFA production, thus, affecting the quality of the palm oil as a result of enzymatic lipase degradation of triglycerides. In addition, the proportion of FFA is related to the moisture content and can accelerate to rancidity levels by increasing the penetration of oxygen into the oil molecule (Hammond and White, 2011; Tan et al., 2017). In the presence of a high moisture content, more FFA could be generated by lipase oxidation or autocatalytic hydrolysis, resulting in rapid development of rancidity (Frank et al., 2011). After bleaching oil with commercial clay and $1.5 \mathrm{M}$ $\mathrm{H}_{2} \mathrm{SO}_{4} \mathrm{Na}$-bentonite, the moisture content was below $0.10 \%$, which could prevent an increase in FFA content (Pal et al., 2015).

The peroxide value is an indicator of oxidative rancidity and deterioration due to lipid peroxidation or oxidative degradation and is, consequently, an important parameter used to assess the quality of palm oil. Moreover, a high peroxide value affects the generation of free radicals, which may have adverse health impacts, such as carcinogenesis (Rossel, 1999). The peroxide value of degummed palm oil was $6.81 \mathrm{meq} \mathrm{kg}^{-1}$, which is lower than the maximum peroxide value recommended by the Codex Alimentarius/FAO/WHO norm (10 meq $\mathrm{kg}^{-1}$ ) (Codex Alimentarius Commission, 2011). After oil was bleached with commercial clay and $1.5 \mathrm{M}$ $\mathrm{H}_{2} \mathrm{SO}_{4} \mathrm{Na}$-bentonite, peroxide values decreased to approximately 2.25 and $2.31 \mathrm{meq} \mathrm{kg}^{-1}$, respectively, indicating good-quality palm oils. In addition, unsaturated fatty acids are recommended for good health over oils with highly saturated fatty acids. However, the iodine value of CPO (57.36 Wijs) is higher than the standard specification (5055 Wijs), which indicates the ease of oxidation of the oil. Interestingly, $1.5 \mathrm{M} \mathrm{H}_{2} \mathrm{SO}_{4}$ Na-bentonite resulted in bleached oil having a lower iodine value (53.52 Wijs) than that obtained from commercial clay application (54.05 Wijs). Because of its anion exchange properties, activated clay often displays a high affinity for anion contaminants, including short- and long-chain alkyl carboxylates, and allows the intercalation of contaminants in the interlayer space (Celis et al.,2014). Moreover, modified clay can provide suitable reaction space for the dimerisation of unsaturated fatty acids and act as a catalyst, which improves dispersibility for the unsaturated fatty acid molecules to enter the interlayer (Huang et al., 2018). A decrease in the iodine value shows a decrease in unsaturated fatty acids, and it indicates oxidation of palm oil, representing a good quality edible oil which has a positive effect on human health (Table 1).

The current results showed that activation of Na-bentonites by $1.5 \mathrm{M} \mathrm{H}_{2} \mathrm{SO}_{4}$ could also reduce the levels of elements such as Fe, which is known to increase the rate of secondary oxidation products (Gibon et al., 2007). Moreover, the presence of high levels of Fe and P can contribute to changes in the flavour, colour and odour of oil. The reduction in the iron content of $1.5 \mathrm{M} \mathrm{H}_{2} \mathrm{SO}_{4} \mathrm{Na}$-bentonite was $0.78 \pm 0.02 \mathrm{mg} \mathrm{kg}^{-1}$, which is less than the maximum acceptable level stipulated in the CODEX standard (1.5 mg kg${ }^{-1}$ ) (Codex Alimentarius Commission, 2011), while commercial clay could reduce the iron content by approximately $1.67 \pm 0.05 \mathrm{mg} \mathrm{kg}^{-1}$ (Table 1). The decrease in content of Fe in the bleached oils was greatest from $1.5 \mathrm{M} \mathrm{H}_{2} \mathrm{SO}_{4} \mathrm{Na}$-bentonite, possibly because it had the optimum $\mathrm{Si}$ and $\mathrm{Al}$ contents. The acid-activated clay shows availability of more adsorption sites in the matrix that are occupied by exchangeable ions in the interlayers. Furthermore, $\mathrm{P}$ adsorbed onto bleaching clays was removed effectively by the adsorbent $1.5 \mathrm{M} \mathrm{H}_{2} \mathrm{SO}_{4}$ Na-bentonite $\left(1.94 \pm 0.07 \mathrm{mg} \mathrm{kg}^{-1}\right)$ and commercial clay $\left(3.13 \pm 0.08 \mathrm{mg} \mathrm{kg}^{-1}\right)$. This information indicated that $1.5 \mathrm{M} \mathrm{H}_{2} \mathrm{SO}_{4} \mathrm{Na}$-bentonite could improve the hydrolytic stability of bleaching oil.

In addition, the most effective adsorbent for palm oil colour removal was activated $\mathrm{Na}$-bentonite. The optimum activation condition was investigated 
TABLE 1. PHYSICOCHEMICAL PROPERTIES OF DEGUMMED PALM OIL BEFORE AND AFTER BLEACHING WITH COMMERCIAL CLAY AND ACTIVATED Na-BENTONITES

\begin{tabular}{|c|c|c|c|}
\hline Physicochemical property & Degummed palm oil & Commercial clay & SBR 1.5 (1:50, 4 hr) \\
\hline Free fatty acid $(\%)$ & $13.65 \pm 0.45^{\mathrm{b}}$ & $8.99 \pm 0.65^{\mathrm{a}}$ & $8.94 \pm 0.31^{\mathrm{a}}$ \\
\hline Moisture content $\left(\mathrm{g} 100 \mathrm{~g}^{-1}\right)$ & $0.23 \pm 0.10^{\mathrm{b}}$ & $0.04 \pm 0.01^{\mathrm{a}}$ & $0.04 \pm 0.01^{\mathrm{a}}$ \\
\hline Peroxide value (meq $\mathrm{kg}^{-1}$ ) & $6.81 \pm 0.20^{\mathrm{b}}$ & $2.25 \pm 0.10^{\mathrm{a}}$ & $2.31 \pm 0.10^{\mathrm{a}}$ \\
\hline Iodine value (Wijs) & $57.36 \pm 0.21^{\mathrm{b}}$ & $54.05 \pm 0.42^{\mathrm{a}}$ & $53.52 \pm 0.15^{\mathrm{a}}$ \\
\hline Iron content $\left(\mathrm{mg} \mathrm{kg}^{-1}\right)$ & $4.13 \pm 0.51^{\mathrm{c}}$ & $1.67 \pm 0.05^{\mathrm{b}}$ & $0.78 \pm 0.02^{\mathrm{a}}$ \\
\hline Phosphorus content $\left(\mathrm{mg} \mathrm{kg}^{-1}\right)$ & $12.56 \pm 0.72^{c}$ & $3.13 \pm 0.08^{\mathrm{b}}$ & $1.94 \pm 0.07^{\mathrm{a}}$ \\
\hline
\end{tabular}

Note: SBR $1.5(1: 50,4 \mathrm{hr})=$ refluxing Na-bentonite with $1.5 \mathrm{M} \mathrm{H}_{2} \mathrm{SO}_{4}$ concentration at $90^{\circ} \mathrm{C}$ for $4 \mathrm{hr}$ and the ratio of clays to acid was $1: 50$ $\left(\mathrm{w} \mathrm{v}^{-1}\right)$. Data are mean $\pm \mathrm{SE}(\mathrm{n}=3)$; different letters in the same row indicate statistically significant differences (Anova test, Duncan, $\mathrm{p}<0.05)$.

TABLE 2. SPECIFIC SURFACE AREA, TOTAL PORE VOLUME, MICRO PORE VOLUME AND AVERAGE PORE SIZE OF COMMERCIAL CLAY AND ACTIVATED Na-BENTONITES

\begin{tabular}{|c|c|c|c|c|}
\hline Sample names & $\begin{array}{c}\text { Specific surface area } \\
\left(\mathrm{m}^{2} \mathrm{~g}^{-1}\right)\end{array}$ & $\begin{array}{l}\text { Total pore volume } \\
\left(\mathrm{cc} \mathrm{g}^{-1}\right)\end{array}$ & $\begin{array}{l}\text { Micro pore volume } \\
\left(\mathrm{cc} \mathrm{g}^{-1}\right)\end{array}$ & Average pore size ( $(\AA)$ \\
\hline Commercial clay & 160.90 & 0.3200 & 0.0900 & 80.47 \\
\hline Ca-bentonite & 42.30 & 0.1010 & 0.0341 & 37.74 \\
\hline Na-bentonite & 67.47 & 0.1256 & 0.0052 & 30.22 \\
\hline SBR $1.5(1: 50,4 \mathrm{hr})$ & 340.50 & 0.4465 & 0.2642 & 48.08 \\
\hline SBR $1.5(5: 50,4 \mathrm{hr})$ & 303.90 & 0.3780 & 0.2184 & $46 . .80$ \\
\hline SBR $1.5(10: 50,4 \mathrm{hr})$ & 270.40 & 0.3164 & 0.1849 & 43.41 \\
\hline SBR 1.5 (10:50, 8 hr) & 373.20 & 0.4672 & 0.2862 & 52.06 \\
\hline SBR $1.5(10: 50,10 \mathrm{hr})$ & 308.40 & 0.4150 & 0.2247 & 46.91 \\
\hline
\end{tabular}

Note: SBR 1.5 (1:50, $4 \mathrm{hr})$, SBR $1.5(5: 50,4 \mathrm{hr})$ and SBR 1.5 (10:50, $4 \mathrm{hr})=$ refluxing Na-bentonite with $1.5 \mathrm{M} \mathrm{H}_{2} \mathrm{SO}_{4}$ concentration at $90^{\circ} \mathrm{C}$ for $4 \mathrm{hr}$ and the ratio of clays to acid was 1:50 $\left(\mathrm{w} \mathrm{v}^{-1}\right), 5: 50\left(\mathrm{w} \mathrm{v}^{-1}\right)$ and $10: 50\left(\mathrm{w} \mathrm{v}^{-1}\right)$, respectively.

at a clay:acid ratio of $1: 50$ with $1.5 \mathrm{M} \mathrm{H}_{2} \mathrm{SO}_{4}$. In this experiment, a comparison of the bleaching capacity of Na-bentonite treated with $1.5 \mathrm{M} \mathrm{H}_{2} \mathrm{SO}_{4}$ at $90^{\circ} \mathrm{C}$ for $4 \mathrm{hr}$ at clay:acid ratios of 1:50, 5:50 and 10:50 $\left(\mathrm{w} \mathrm{v}^{-1}\right)$ was performed. The result showed that increasing the clay:acid ratio caused a decrease in the bleaching capacity (Figure 3). When the clay:acid ratio was increased from 1:50 to $10: 50\left(\mathrm{w} \mathrm{v}^{-1}\right)$, the structure of the clay slowly collapsed, lowering the specific surface area and total pore volume (Table 2). Therefore, a longer refluxing time was needed in the leaching process to investigate the most suitable conditions and $\mathrm{SiO}_{2}$ and $\mathrm{Al}_{2} \mathrm{O}_{3}$ contents. The result showed that increasing the refluxing time from $4 \mathrm{hr}$ (minimum) to 6-8 $\mathrm{hr}$ increased the bleaching capacity of activated Na-bentonite, but at the clay:acid ratio equal to $10: 50\left(\mathrm{w} \mathrm{v}^{-1}\right)$, the optimum time was $8 \mathrm{hr}(78.04 \%)$. The longer time of $10 \mathrm{hr}$ might have destroyed the clay structure and thus, giving a lower bleaching capacity $(72.70 \%)$ than 8 $\mathrm{hr}$. Therefore, the best activation condition of Nabentonite was at $\mathrm{H}_{2} \mathrm{SO}_{4}$ concentration of $1.5 \mathrm{M}$ at $90^{\circ} \mathrm{C}$ for $8 \mathrm{hr}$ at a clay:acid ratio of 10:50 $\left(\mathrm{w} \mathrm{v}^{-1}\right)$, which resulted in the clay with the highest bleaching capacity (approximately 78.04\%). Alternatively, the ratio of 5:50 $\left(\mathrm{w} \mathrm{v}^{-1}\right)$ and a time of $4 \mathrm{hr}$ could also be applied in industry because the bleaching efficiency was only a little lower than that given by a ratio of 1:50 $\left(\mathrm{w} \mathrm{v}^{-1}\right)\left(1.5 \mathrm{M} \mathrm{H}_{2} \mathrm{SO}_{4^{\prime}} 4 \mathrm{hr}\right)$, but the amount of clay used in the refluxing process increased by up to five times.

\section{CONCLUSION}

The bleaching capacities were correlated with $\mathrm{SiO}_{2}$ and $\mathrm{Al}_{2} \mathrm{O}_{3}$ contents in bleaching clay. The most suitable clay for bleaching contained $\mathrm{SiO}_{2}$ and $\mathrm{Al}_{2} \mathrm{O}_{3}$ in the range of $68.90 \%-85.20 \%$ and $8.96 \%-16.60 \%$ by wt, respectively. This knowledge can be applied to modify other Na-bentonites from other sources to bleach palm oil efficiently. In this study, $1.5 \mathrm{M}$ $\mathrm{H}_{2} \mathrm{SO}_{4}$-treated Na-bentonite was a suitable clay for bleaching palm oil. The best activation condition was Na-bentonite refluxed with $1.5 \mathrm{M} \mathrm{H}_{2} \mathrm{SO}_{4}$ solution at $90^{\circ} \mathrm{C}$ for $8 \mathrm{hr}$ at a clay:acid ratio of $10: 50\left(\mathrm{w} \mathrm{v}^{-1}\right)$. Activated Na-bentonites could decolourise palm oil better than activated $\mathrm{Ca}$-bentonite and commercial clay. Moreover, $1.5 \mathrm{M} \mathrm{H}_{2} \mathrm{SO}_{4} \mathrm{Na}$-bentonite was also giving the good results for the adsorption of FFA and in the elimination of peroxide, iodine, $\mathrm{Fe}, \mathrm{P}$ and moisture contents. It appeared clear that activated Na-bentonite could give an attractive colour to palm oil, and also produce a stable oil of good quality. 


\section{ACKNOWLEDGEMENT}

This research was supported by King Mongkut's University of Technology Thonburi, Thailand.

\section{REFERENCES}

Afolabi, R O; Orodu, O D and Efeovbokhan, V E (2017). Properties and application of Nigerian bentonite clay deposits for drilling mud formulation: Recent advances and future prospects. Appl. Clay Sci., 143: 39-49. DOI: 10.1016/j.clay.2017.03.009.

Aung, L L; Tertre, E; Suksabye, P; Worasith, N and Thiravetyan, P (2015). Effect of alumina content and surface area of acid-activated kaolin on bleaching of rice bran oil. J. Amer. Oil Chem. Soc., 92: 295-304. DOI: 10.1007 / s11746-015-2625-4.

Aung, L L; Tertre, E; Worasith, N; Suksabye, P and Thiravetyan, P (2014). The capacity of activated kaolins to remove colour pigments from rice bran oil: The effects of acid concentration and preheating prior to activation. Clay Miner., 49: 513-526. DOI: 10.1180/ claymin.2014.049.4.02.

Ayari, F; Srasra, E and Trabelsi-Ayadi, M (2005). Characterization of bentonitic clays and their use as adsorbent. Desalination, 185: 391-397. DOI: $10.1016 /$ j.desal.2005.04.046.

Baptiste, B M J; Daniele, B K; Charléne, E M; Canuala, T T L; Antoine, E and Richard, K (2020). Adsorption mechanisms of pigments and free fatty acids in the discoloration of shea butter and palm oil by an acid-activated Cameroonian smectite. Sci. Afr., 9: e00498. DOI: 10,1016/j.sciaf. 2020.e00498.

Celis, R; Ángeles Adelino, M: Gámiz, B; Carmen Hermosín, M; Koskinen, W C and Cornejo, J (2014). Nanohybrids of $\mathrm{Mg} / \mathrm{Al}$ layered double hydroxide and long-chain (C18) unsaturated fatty acid anions: Structure and sorptive properties. Appl. Clay Sci., 96: 81-90. DOI: 10.1016/j.clay.2014. 03.026 .

Christidis, G E and Kosiari, S (2003). Decolorization of vegetable oils: A study of the mechanism of adsorption of $\beta$-carotene by an acid-activated bentonite from Cyprus. Clays Clay Miner., 51: 327333. DOI: 10.1346/CCMN.2003.0510309.

Codex Alimentarius Commission (2011). Codex Standards for Named Vegetable Oils, CODEXSTAN 210-1999, Food and Agriculture Organization of the United Nations/World Health Organization (FAO/WHO).
Cunniff, P (1997). Official Methods of Analysis of AOAC International, $16^{\text {th }}$ edition. AOAC International, Gaithersburg, Maryland.

Fernandez, R; Martirena, F and Scrivener, K L (2011). The origin of the pozzolanic activity of calcined clay minerals: A comparison between kaolinite, illite and montmorillonite. Cem. Concr. Res., 41: 113-122. DOI: 10.1016/j.cemconres.2010.09.013.

Firestone, D (1997). Official Methods and Recommended Practices of the American Oil Chemists' Society, $5^{\text {th }}$ edition. AOCS Press, Champaign IL.

Foo, C T; Mahmood, C S and Salleh, M A M (2011). The study of aluminum loss and consequent phase transformation in heat-treated acid-leached kaolin. Mater. Charact., 62: 373-377. DOI: 10.1016/j. matchar.2011.01.017.

Frank, N E G; Albert, M M E; Laverdure, D E E and Paul, K (2011). Assessment of the quality of crude palm oil from smallholders in Cameroon. J. Stored Prod. Postharvest Res., 2: 52-58.

Gibon, V; Greyt, W De and Kellens, M (2007). Palm oil refining. Eur. J. Lipid Sci. Technol., 109: 315-335. DOI: $10.1002 /$ ejlt.200600307.

Girgis, A Y (2005). Reuse of discarded deactivated bleaching earths in the bleaching of oils. Grasas $y$ Aceites, 56: 34-45. DOI: 10.3989/gya.2005.v56.i1.132.

Gunawan, N S; Indraswati, N; Ju, Y H; Soetaredjo, F E; Ayucitra, A and Ismadji, S (2010). Bentonites modified with anionic and cationic surfactants for bleaching of crude palm oil. Appl. Clay Sci., 47: 462464. DOI: 10.1016/j.clay.2009.11.037.

Hammond, E G and White, P J (2011). A brief history of lipid oxidation. J. Amer. Oil Chem. Soc., 88: 891-897. DOI: $10.1007 /$ s11746-011-1761-8.

Hassan, M S and Abdel-Khalek, N A (1998). Beneficiation and applications of an Egyptian bentonite. Appl. Clay Sci., 13: 99-115. DOI: 10.1016/ S0169-1317(98)00021-0.

Huang, X; Yin, Y; Zhanga, B and Feng, G (2018). Effects of the structure and composition of montmorillonite on the dimerization of unsaturated fatty acids. J. Braz. Chem. Soc., 29: 1516-1526. DOI: 10.21577/0103-5053.20180025.

Ismail, M I; Hamidon, M H; Sofi, M Z M and Azmi, N S (2016). Renewable bleaching alternative (RBA) for palm oil refining from waste materials. J. Appl. Environ. Biol. Sci., 6: 52-57. 
Jorhem, L (2000). Determination of metals in foods by atomic absorption spectrometry after dry dshing: NMKL collaborative study. J. AOAC Int., 83: 12041211.

Joy, N A B; Pierre, K R and Pierre, N J (2007). Adsorption of palm oil carotene and free fatty acids onto acid activated Cameroonian clays. J. Appl. Sci., 7: 2462-2467. DOI: 10.3923 / jas.2007.2462.2467.

Kashani Motlagh, M M; Youzbashi, A A and Amiri Rigi, Z (2011). Effect of acid activation on structural and bleaching properties of a bentonite. Iran J. Mater. Sci. Eng., 8: 50-56.

Khor, Y P; Sim, B I; Abas, F; Lai, O M; Wang, Y; Wang, Y and Tan, C P (2019). Quality profile determination of palm olein: Potential markers for the detection of recycled cooking oils. Int. J. Food Prop., 22: 1172-1182. DOI: 10.1080/10942912.2019.1634098.

Lau, S Y; Phuan, S L; Danquah, M K and Acquah, C (2019). Sustainable palm oil refining using pelletized and surface-modified oil palm boiler ash (OPBA) biosorbent. J. Clean Prod., 230: 527-535. DOI: 10.1016/j.jclepro.2019.04.390.

Meesuk, L and Seammai, S (2010). The use of perlite to remove dark colour from repeatedly used palm oil. ScienceAsia, 36: 33-39. DOI: 10.2306/ scienceasia1513-1874.2010.36.033.

Nde, H S; Tamfuh, P A; Clet, G; Vieillard, J; Mbognou, M T and Woumfo, E D (2019). Comparison of $\mathrm{HCl}$ and $\mathrm{H}_{2} \mathrm{SO}_{4}$ for the acid activation of a Cameroonian smectite soil clay: Palm oil discolouration and landfill leachate treatment. Heliyon, 5: e02926. DOI: 10.1016/j.heliyon.2019.e02926.

Nwabanne, J T and Ekwu, F C (2013). Decolourization of palm oil by Nigerian local clay: A study of adsorption isotherms and bleaching kinetics. Int. J. Multidiscip. Sci. Eng., 4: 20-25.

Pal, U S; Patra, R K; Sahoo, N R; Bakhara, C K and Panda, M K (2015). Effect of refining on quality and composition of sunflower oil. J. Food Sci. Technol., 52: 4613-4618. DOI: 10.1007/s13197-014-1461-0.

Rossel, J B (1999). Measurement of rancidity. Rancidity in Foods (Allen, J C and Hamilton, R J eds.). $3^{\text {rd }}$ edition. Aspen Publishers, London. p. 2253.
Rossi, M; Gianazza, M; Alamprese, C and Stanga, F (2003). The role of bleaching clays and synthetic silica in palm oil physical refining. Food Chem., 82: 291-296. DOI: 10.1016/S0308-8146(02)00551-4.

Rossi, M; Gianazza, M; Alamprese, C and Stanga, F (2011). The effect of bleaching and physical refining on color and minor components of palm oil. J. Amer. Oil Chem. Soc., 78: 1051-1055. DOI: 10.1007/s11746001-0387-8.

Salawudeen, T O; Dada, E O and Alagbe, S O (2007). Performance evaluation of acid treated clays for palm oil bleaching. J. Eng. Appl. Sci., 2: 1677-1680.

Silva, S M; Sampaio, K A; Ceriani, R; Verhé, R; Stevens, C; De Greyt, W and Meirelles, A J A (2013). Adsorption of carotenes and phosphorus from palm oil onto acid activated bleaching earth: Equilibrium, kinetics and thermodynamics. J. Food Eng., 118: 341349. DOI: 10.1016/j.jfoodeng.2013.04.026.

Tan, C H; Ariffin, A A; Ghazali, H M; Tan, C P; Kuntom, A and Choo, A C Y (2017). Changes in oxidation indices and minor components of low free fatty acid and freshly extracted crude palm oils under two different storage conditions. J. Food Sci. Technol., 54: 1757-1764. DOI: $10.1007 /$ s13197-0172569-9.

Tebandeke, I Z M; Ssebuwufu, P J M; Nyanzi, S A; Schumann, A; Nyakairu, G W and Lugolobi, F (2014). Using trace metals, peroxide, acid and iodine values to characterize oils bleached using clays from central and eastern Uganda. Am. J. Analyt. Chem., 5: 1302-1312. DOI: $10.4236 /$ ajac.2014.517136.

Temuujin, J; Senna, M; Jadambaa, T; Burmaa, D; Erdenechimeg, S and MacKenzie, K J D (2006). Characterization and bleaching properties of acidleached montmorillonite. J. Chem. Technol. Biotechnol., 81: 688-693. DOI: 10.1002 / jctb.1469.

Usman, M A; Oribayo, O and Adebayo, A A (2013). Bleaching of palm oil by activated local bentonite and kaolin clay from Afashio, Edo-Nigeria. Chem. Process Eng. Res., 10: 1-12.

Warasith, N and Goodman, B A (2020). Activated kaolin minerals as bleaching clays for prolonging the useful life of palm oil in industrial frying operations. J. Amer. Oil Chem. Soc., 97: 389-396. DOI: 10.1002/ aocs.12327. 